\title{
Determination of Picloram in Waters by Sequential Injection Chromatography with UV Detection
}

\author{
Luciana B. O. dos Santos, ${ }^{a}$ Carlos M. C. Infante ${ }^{b}$ and Jorge C. Masini ${ }^{b, *}$ \\ ${ }^{a}$ Departamento de Ciências Exatas e da Terra, Universidade do Estado da Bahia, \\ Estrada das Barreiras, s/n, 41195-001 Salvador-BA, Brazil
}

${ }^{b}$ Instituto de Química, Universidade de São Paulo, CP 26077, 05513-970 São Paulo-SP, Brazil

\begin{abstract}
Este trabalho descreve um procedimento de cromatografia por injeção seqüencial para a determinação de picloram em águas explorando a baixa pressão de uma coluna monolítica $\mathrm{C}_{18} \mathrm{de}$ $2,5 \mathrm{~cm}$ de comprimento. A separação do analito da matriz foi obtida em menos de $60 \mathrm{~s}$ usando como fase móvel uma mistura de acetonitrila e $\mathrm{H}_{3} \mathrm{PO}_{4} 5,0 \mathrm{mmol} \mathrm{L}{ }^{-1}$ na proporção 20:80 ( $\left.\mathrm{v} \mathrm{v}^{-1}\right)$ e vazão de $30 \mu \mathrm{L} \mathrm{s}^{-1}$. Detecção foi feita a $223 \mathrm{~nm}$ com uma cela de $40 \mathrm{~mm}$ de caminho óptico. O limite de detecção do método é adequado para monitorar o nível de concentração máximo permitido para picloram em água potável $\left(500 \mu \mathrm{g} \mathrm{L}^{-1}\right)$. A frequência de amostragem é de 60 análises por hora, consumindo $300 \mu \mathrm{L}$ de acetonitrila por análise. A metodologia foi aplicada a águas de rio fortificadas, não sendo observadas diferenças estatisticamente significativas em comparação com a metodologia convencional de HPLC-UV.
\end{abstract}

This paper describes a sequential injection chromatography procedure for determination of picloram in waters exploring the low backpressure of a $2.5 \mathrm{~cm}$ long monolithic $\mathrm{C}_{18}$ column. Separation of the analyte from the matrix was achieved in less than $60 \mathrm{~s}$ using a mobile phase composed by 20:80 ( $\left.\mathrm{v} \mathrm{v}^{-1}\right)$ acetonitrile:5.0 $\mathrm{mmol} \mathrm{L}^{-1} \mathrm{H}_{3} \mathrm{PO}_{4}$ and flow rate of $30 \mu \mathrm{L} \mathrm{s}^{-1}$. Detection was made at $223 \mathrm{~nm}$ with a $40 \mathrm{~mm}$ optical path length cell. The limits of detection and quantification were 33 and $137 \mu \mathrm{g} \mathrm{L}^{-1}$, respectively. The proposed method is sensitive enough to monitor the maximum concentration level for picloram in drinking water $\left(500 \mu \mathrm{g} \mathrm{L}^{-1}\right)$. The sampling frequency is 60 analyses per hour, consuming only $300 \mu \mathrm{L}$ of acetonitrile per analysis. The proposed methodology was applied to spiked river water samples and no statistically significant differences were observed in comparison to a conventional HPLC-UV method.

Keywords: sequential injection chromatography, monolithic column, picloram, waters

\section{Introduction}

The presence of pesticides in surface and ground waters is a consequence of the extensive use of these chemicals in agriculture and their runoff down through the soil profile. ${ }^{1}$ Picloram (4-amino-3,5,6-trichloro-2-pyridinecarboxilic acid) is a herbicide widely used to control weeds in crops of sugar cane (pre-emergency), rice, pasture and wheat (pos-emergency). ${ }^{2}$ This herbicide can stay active in soil for long time, depending on the type of soil, soil moisture and temperature. It may exist at toxic levels to plants for more than one year after application at normal rates. ${ }^{2,3}$ It is chemically adsorbed onto clay particles and natural organic matter occurring in soils. If the soil is poor in clay

*e-mail: jcmasini@iq.usp.br or organic matter contents, the herbicide may be easily leached to surface and ground waters..$^{3-6}$

Determination of picloram is usually made by gas-liquid chromatography with electron capture detector or mass spectrometry detectors, ${ }^{7}$ although several high performance liquid chromatography methods have already been proposed using either UV absorption or mass spectrometry detection modes. ${ }^{8-11}$ These methods are very sensitive, but require the use of large sample volumes, besides to extensive extraction steps, derivatization reactions and expensive instrumentation, so that new sensitive methods that reduce the time of analysis and the use of organic solvents are needed. Electroanalytical methods are known to attend the demand for minimal sample treatment and low consumption of organic solvents, ${ }^{12,13}$ but these techniques are liable to matrix effects such as passivation 
of the electrode surface by naturally occurring organic matter, besides to interference from any other electroactive substances with $\mathrm{E}_{1 / 2}$ close to that one of the analyte.

Sequential injection chromatography (SIC) is a relatively new liquid chromatography technique ${ }^{14}$ that explores the potentialities of sequential injection analysis for flow programming ${ }^{15}$ and the low backpressures provided by $\mathrm{C}_{18}$ monolithic stationary phases. This technique uses low cost instrumentation and has been applied especially in the determination of components of pharmaceutical products ${ }^{16}$ although determinations of herbicides and pesticides ${ }^{17,18}$ and amino acids ${ }^{19}$ have been described. The present paper shows that the SIC capabilities for separation of simple mixtures can be explored for monitoring the maximum concentration levels of picloram in natural waters. ${ }^{20}$ To achieve this goal a SIC method was developed and applied for determination of the herbicide in spiked natural waters collected in the São Paulo State, Brazil.

\section{Experimental}

\section{Apparatus and reagents}

A SIChrom ${ }^{\mathrm{TM}}$ - accelerated liquid chromatography system was provided by FIAlab® Instruments (Bellevue, WA, USA) and schematized in Figure 1, where PP is a piston pump model S17 PDP from Sapphire Engineering TM (Pocasset, MA, USA) with capacity of $4.0 \mathrm{~mL}$, built in ULTEM ${ }^{\circledR}$, having a ceramic piston $(\mathrm{P})$ for solution propelling and aspiration. The frontal port (FP) of PP is connected to the central port of a rotary selection valve (SV) by the holding coil (HC), which is made of $2 \mathrm{~m}$ of $0.8 \mathrm{~mm}$ i.d. Teflon tubing (capacity of $1.0 \mathrm{~mL}$ ). The rear port $\left(\mathrm{RP}_{1}\right)$ of $\mathrm{PP}$ is connected to the main solvent reservoir $\left(\mathrm{MP}_{1}\right)$ through ports 9 and 10 of SV (Figure 1). An additional port in the pump body $\left(\mathrm{RP}_{2}\right)$ is connected through a 4-way valve to a relief valve (RV) from UpChurch Scientific (Oak Harbor, WA, USA) that opens to waste at pressure $>500 \mathrm{psi}$. A Cheminert ${ }^{\circledR}$ Valco10-port multi-position valve (SV) model C25 stream selector C25-3180 EMH (Valco Instruments, Houston, TX, USA) was used to select and drive sample and mobile phase solutions though the system. Port 2 of SV is connected to a $5 \mathrm{~mm}$ long guard column coupled to a $25 \mathrm{~mm}$ reverse phase $\mathrm{C}_{18}$ Chromolith Flash monolithic column, both from Merck KGaA (Darmstadt, Germany). Detection was made by molecular absorbance spectrophotometry using an USB 4000 spectrometer (Ocean Optics, Dunedin, FL, USA) coupled to an SMA-Z-40 $\mu$ vol PEEK flow cell (FIAlab Instruments, Bellevue, WA, USA) with $40 \mathrm{~mm}$ of optical path length and $10 \mu \mathrm{L}$ of internal volume.

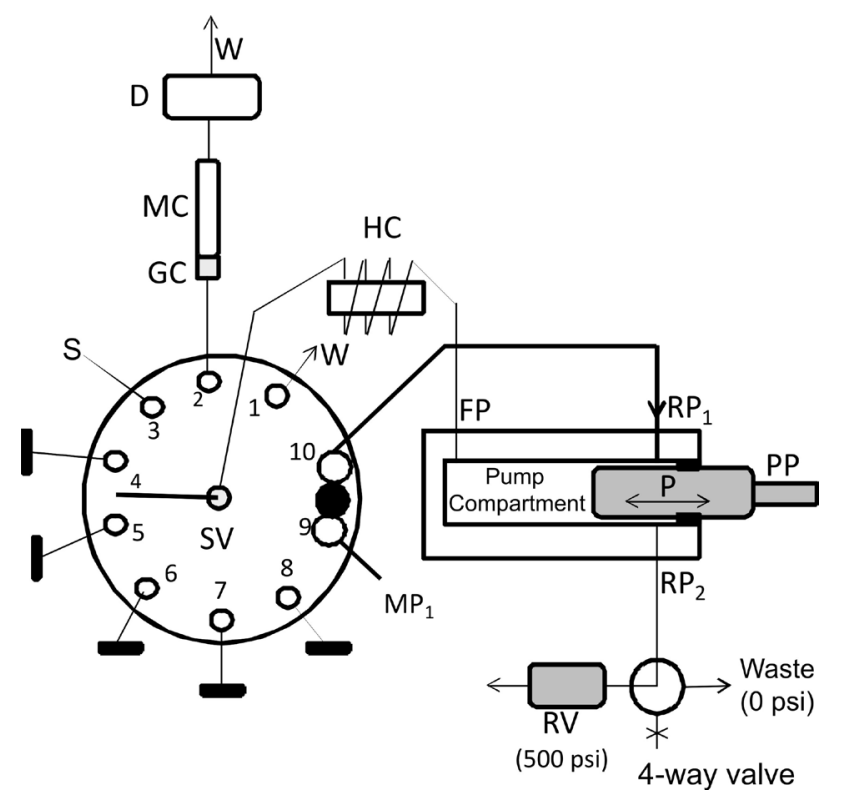

Figure 1. SIC manifold to perform determination of picloram in river waters. $\mathrm{PP}=$ piston pump, $\mathrm{P}=$ piston; $\mathrm{RP}_{1}=$ rear port $1, \mathrm{RP}_{2}=$ rear port 2 , $\mathrm{RV}=$ relief valve, $\mathrm{HC}=$ holding coil $(2 \mathrm{~m}$ of $0.8 \mathrm{~mm}$ i.d. PTFE tubing $)$, $\mathrm{W}=$ waste, $\mathrm{SV}=10$ port selection valve, $\mathrm{GC}=5 \mathrm{~mm} \mathrm{C}_{18}$ monolithic guard column, $\mathrm{MC}=25 \mathrm{~mm} \mathrm{C}_{18}$ monolithic column, $\mathrm{D}=\mathrm{UV}$-Vis detector $(223 \mathrm{~nm}), \mathrm{S}=$ sample/standard solution, $\mathrm{MP}_{1}=$ mobile phase for isocratic elution composed by 20:80 ACN: $5.0 \mathrm{mmol} \mathrm{L}^{-1} \mathrm{H}_{3} \mathrm{PO}_{4}$. The selection valve is shown in the fill-position, in which a circular groove connects ports 9 and 10 allowing the pump to fill. In any other rotor position, the circular groove does not connect adjacent ports.

A DH 2000 Deuterium Tungsten Halogen lamp (Mikropack $\mathrm{GmbH}$, Germany) was used as light source. Two $600 \mu \mathrm{m}$ diameter optical fibers (20 inches long) were used to transmit radiation from the source to the flow cell and to the spectrometer. Connections of port 2 of SV to the precolumn and from the column outlet to flow cell are made, respectively, with 40 and $18 \mathrm{~cm}$ long $0.25 \mathrm{~mm}$ i.d. PEEK (polyetheretherketone polymer) tubing. Connection of the $\mathrm{MP}_{1}$ reservoir to SV (port 9) is made with $1 / 8$ o.d. Teflon tubing. Connection of SV (port 10) to RP of PP is made with $1.0 \mathrm{~mm}$ i.d. PEEK tubing. Port 3 of SV is connected to the sample reservoir (S), and, to minimize the sample consumption, this connection is made with $15 \mathrm{~cm}$ of $0.25 \mathrm{~mm}$ i.d. PEEK tubing $(7.4 \mu \mathrm{L})$. Ports 4 to 8 were not used in the proposed methodology and were kept blocked with solid Teflon tubing. The system is controlled by the FIAlab for Windows software.

An LC 9A Shimadzu high performance liquid chromatograph (HPLC), equipped with a SPD 6 AV UV detector and the LC Workstation Class-LC 10 software was used in comparison studies. An SBC18 Zorbax-HP column $(3.5 \mu \mathrm{m}, 150 \mathrm{~mm} \times 4.6 \mathrm{~mm})$ connected to a $\mathrm{C} 18$ Phenomenex guard column was used. Sample injection was made with a rotary Rheodyne valve using a $20 \mu \mathrm{L}$ sample loop. 
Acetonitrile (ACN) of HPLC grade was supplied by J.T. Baker (Phillipsburg, NJ, USA). Water used in all experiments was distilled and deionized using the Simplicity 185 system from Millipore (Billerica, MA, USA) coupled to an UV lamp. Mobile phases were filtered through $0.45 \mu \mathrm{m}$ LCR-PTFE membranes prior to use. In all experiments a helium stream was used to remove dissolved air from the mobile phases. All other reagents used in this work were of analytical grade from Merck, Sigma or Aldrich. A stock $1000 \mu \mathrm{g} \mathrm{L}{ }^{-1}$ solution of picloram was prepared by dissolving the solid standard (Riedel-de Haën, purity $>97.4 \%$, molar mass $241.46 \mathrm{~g} \mathrm{~mol}^{-1}$ ) in ethanol. Working solutions were prepared by diluting these stock solutions in distilled deionized water.

\section{Analysis of picloram}

First, the pump compartment of PP, as well as HC, and the flow cell are filled with the mobile phase $\mathrm{MP}_{1}$ composed by $(20: 80)$ ACN: $5.0 \mathrm{mmol} \mathrm{L}^{-1}$ phosphoric acid. Column conditioning was made by performing three cycles of aspiration of $4.0 \mathrm{~mL}$ of $\mathrm{MP}_{1}$ inside the pump compartment at a flow rate of $100 \mu \mathrm{L} \mathrm{s}^{-1}$, followed by emptying the pump through port 2 of SV, which is connected to GC, MC and D (Figure 1), at a flow rate of $30 \mu \mathrm{L} \mathrm{s}^{-1}$. Cleansing of the sampling line is made by aspirating $50 \mu \mathrm{L}$ of sample or standard to the holding coil, followed by discarding $300 \mu \mathrm{L}$ (sample plus mobile phase) through port 1 of the selection valve. For calibration and analysis $1500 \mu \mathrm{L}$ of $\mathrm{MP}_{1}$ are aspirated inside the pump compartment through ports 9 and 10 of SV (Figure 1), followed by aspiration of $100 \mu \mathrm{L}$ of sample/standard solution inside HC through port 3 of $\mathrm{SV}\left(100 \mu \mathrm{L} \mathrm{s}^{-1}\right)$. Next, the pump is emptied through port 2 at a flow rate of $30 \mu \mathrm{L} \mathrm{s}^{-1}$, performing the sample injection and analyte elution simultaneously to the acquisition data from the UV-Vis detector. Ports 4 to 8 of SV are blocked.

HPLC analyses of picloram were made by isocratic elution with a mobile phase constituted by (50:50) acetonitrile : $0.10 \%(\mathrm{~m} / \mathrm{v})$ phosphoric acid. The analyses were made at a flow rate of $1.0 \mathrm{~mL} \mathrm{~min}{ }^{-1}$ and injecting a sample volume of $20 \mu \mathrm{L}$. The UV detector monitored the absorbance at $223 \mathrm{~nm}$.

\section{Samples}

Water samples were collected in two reservoirs located in the metropolitan area of São Paulo (Brazil) used as water supplies for São Paulo City. Other samples were collected in reservoirs of Atibaia River, near to the municipality of Americana (São Paulo State), in an agricultural area dominated by sugar cane cultivation, where herbicides are extensively used. A tap water sample collected at the laboratory was also analyzed. Water samples were filtered through a $0.45 \mu \mathrm{m}$ cellulose acetate membrane and stored in glass bottles at $4{ }^{\circ} \mathrm{C}$. Quantification was performed by external calibration, preparing the standards in deionized water. Blank in all experiments was deionized water. Recovery experiments were performed by spiking the samples with $0.50 \mathrm{mg} \mathrm{L}^{-1}$ of picloram, adopting a delay time of $24 \mathrm{~h}$ between the spike and the analysis.

\section{Results and Discussion}

\section{Method development}

The composition of the mobile phase was studied by varying the content of $\mathrm{ACN}$ from 10 to $30 \%$ (v/v) in relation to the $5.0 \mathrm{mmol} \mathrm{L}^{-1} \mathrm{H}_{3} \mathrm{PO}_{4}$ aqueous phase. The $30: 90 \mathrm{ACN}$ : $5.0 \mathrm{mmol} \mathrm{L}^{-1} \mathrm{H}_{3} \mathrm{PO}_{4}$ did not provide suitable separation between picloram and the unretained peak. Mobile phase constituted by 20:80 ACN:5.0 mmol L-1 $\mathrm{H}_{3} \mathrm{PO}_{4}$ provided the best compromise between separation of picloram from the matrix and the length of the chromatographic runs, which were unnecessarily increased at lower $\mathrm{ACN}$ concentrations (10:90 ACN:5.0 mmol L-1 $\mathrm{H}_{3} \mathrm{PO}_{4}$ ).

The influence of sample volume was studied by injecting 25 to $200 \mu \mathrm{L}$ of a $5.0 \mathrm{mg} \mathrm{L}^{-1}$ picloram solution. Peak areas increased linearly with the sample volume $\left(S_{v}\right)$ up to $100 \mu \mathrm{L}$, obeying the equation Area $=(0.0223 \pm 0.002)$ $\mathrm{S}_{\mathrm{v}}+(0.01 \pm 0.02), \mathrm{r}=0.9998$, but for larger volumes the signals leveled off and carryover between subsequent injections was observed, so that $100 \mu \mathrm{L}$ was used in the application of the method. Flow rates between 10 and $60 \mu \mathrm{L} \mathrm{s}^{-1}$ were studied. Although at $60 \mu \mathrm{L} \mathrm{s}^{-1}$ the analysis could be made in about $30 \mathrm{~s}$, implying in a sampling throughput of 120 analyses per hour, the flow rate of $30 \mu \mathrm{L} \mathrm{s}^{-1}$ was used in the next studies to avoid leaking problems through the relief valve (RV, Figure 1), reaching a sampling throughput of 60 analyses per hour. Flow rate of $30 \mu \mathrm{L} \mathrm{s}^{-1}$ is not applicable with conventional syringe pumps conventionally used in SIA systems because of phase mobile leaking through the two way syringe valve..$^{16}$

\section{Figures of merit}

The repeatability of the method was evaluated at two concentration levels, 0.25 and $5.0 \mathrm{mg} \mathrm{L}^{-1}$, resulting in variation coefficients of 4.4 and $1.0 \%$, respectively. Figure 2 shows the chromatograms of a typical calibration curve for picloram concentrations between 0.25 and $5.0 \mathrm{mg} \mathrm{L}^{-1}$, obtained by injecting a sample volume of $100 \mu \mathrm{L}$ and eluting the column at a flow rate of $30 \mu \mathrm{L} \mathrm{s}^{-1}$. Peak area (Y) versus picloram concentrations (C) fitted to the linear equation 


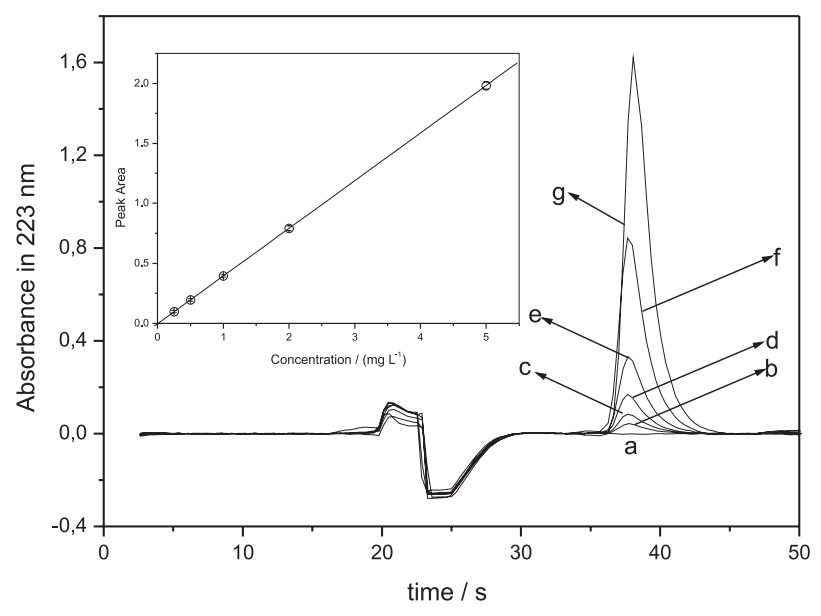

Figure 2. Sequential Injection Chromatograms for calibration of the SIC system obtained by injecting $100 \mu \mathrm{L}$ of standard at flow rate of $30 \mu \mathrm{L} \mathrm{s}^{-1}$ in a mobile phase composed by 20:80 ACN: $5.0 \mathrm{mmol} \mathrm{L}^{-1} \mathrm{H}_{3} \mathrm{PO}_{4}$ Picloram concentrations of the calibration solutions were: (a) blank, (b) 0.25 , (c) 0.50 , (d) 1.0 , (e) 2.0 , (f) $5.0 \mathrm{e}$ (g) $10 \mathrm{mg} \mathrm{L}^{-1}$. The inset shows the linear correlation between peak area and picloram concentration.

$\mathrm{Y}=(0.397 \pm 0.001) \mathrm{C}-(0.002 \pm 0.001)$ with $\mathrm{r}=0.9998$ The limits of detection (LOD) and quantification (LOQ) were 33 and $137 \mu \mathrm{g} \mathrm{L}^{-1}$, respectively. These parameters were computed as $\mathrm{LOD}=3 \sigma / S$ and $\mathrm{LOQ}=10 \sigma / S$, where $\sigma$ is the standard deviation of ten peak area measurements corresponding to the $0.25 \mathrm{mg} \mathrm{L}^{-1}$ solution and $S$ is the slope of the analytical curve. ${ }^{21}$ The Environmental Protection Agency (EPA) defines the maximum contaminant level (MCL) for picloram in drinking water as $0.50 \mathrm{mg} \mathrm{L}^{-1},{ }^{20}$ so that the proposed method, even using the short $25 \mathrm{~mm}$ column, is sensitive enough for monitoring picloram.

\section{Selectivity}

Figure 3 shows the ultraviolet absorption of picloram superposed to typical river water and spiked river water spectra, showing that the chromatographic separation is needed because natural organic matter (humic substances, polysaccharides etc) and inorganic ions such as nitrate and nitrite strongly absorb radiation in the ultraviolet region. On the other hand, these substances are polar and do not interact with the $\mathrm{C}_{18}$ stationary phase, being eluted from the column together with the unretained peak of the sample solvent (Figure 4). Chromatograms of spiked river water sample (Figure 4) shows that the mobile phase composed by 20:80 ACN:5.0 mmol L-1 $\mathrm{H}_{3} \mathrm{PO}_{4}$ conferred adequate selectivity toward the sample matrix. Additionally, because picloram is used in the agriculture in combination with other herbicides such as glyphosate, 2,4 $\mathrm{D}$ and paraquat, the potential interference of these compounds was studied at a concentration ratio of $1: 20$ for each compound $\left(0.50 \mathrm{mg} \mathrm{L}^{-1}\right.$ picloram plus $10 \mathrm{mg} \mathrm{L}^{-1}$ of the foreigner herbicide). No

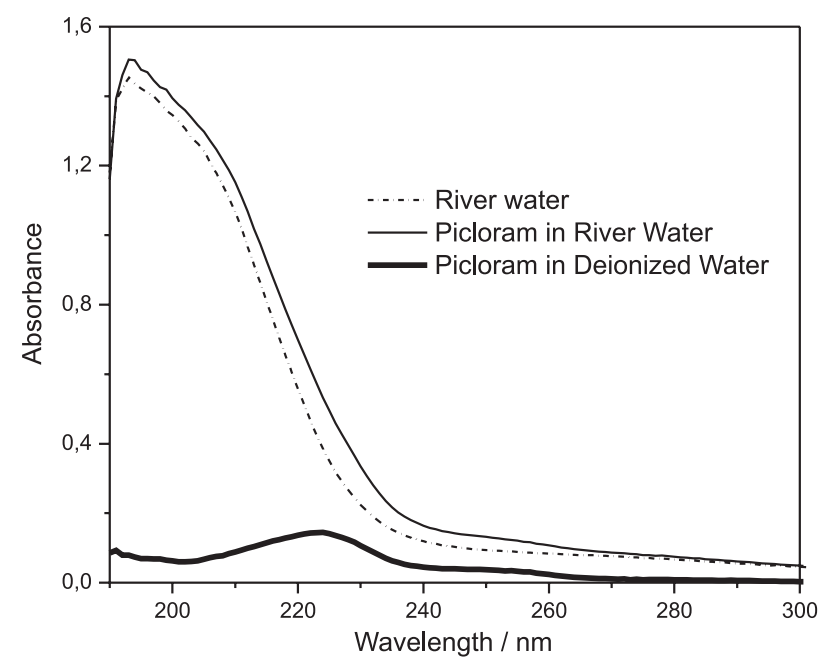

Figure 3. Absorption spectrum of a $0.50 \mathrm{mg} \mathrm{L}^{-1}$ picloram solution in deionized water superposed to the spectra of a river water sample and river water spiked with $0.50 \mathrm{mg} \mathrm{L}^{-1}$ of picloram.

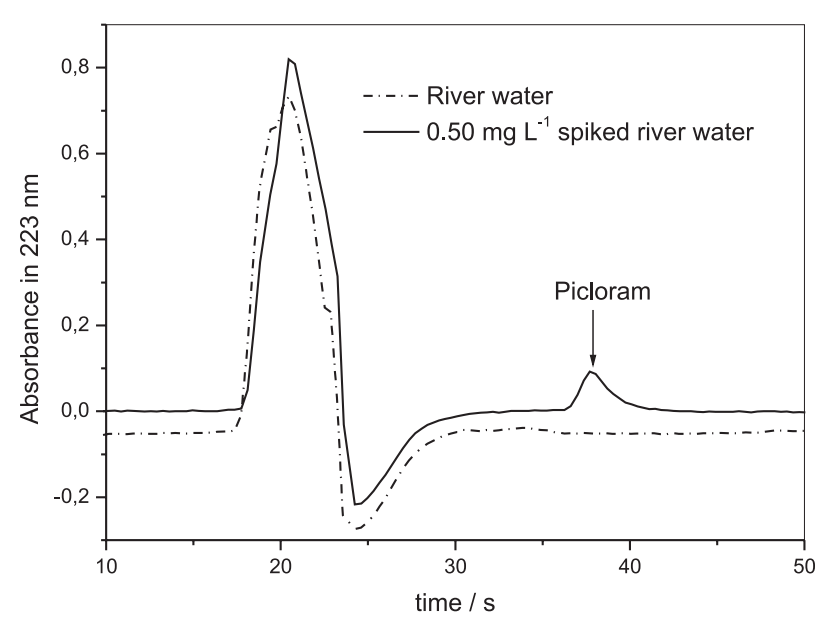

Figure 4. Sequential injection chromatograms of a picloram free river water superposed to a chromatogram of the same sample spiked with $0.50 \mathrm{mg} \mathrm{L}^{-1}$ of picloram, exhibiting the absence of interference peaks in the retention time of the analyte. The large and high peak at $20.5 \mathrm{~s}$ is assigned to unretained substances with strong absorption of UV radiation.

significant interference was observed because glyphosate and paraquat are not retained in the stationary phase and 2,4 D elutes at distinct retention time in relation to picloram. Interference of triazine herbicides such as simazine, atrazine and propazine is not expected because these compounds require mobile phase containing higher volumetric ratio of acetonitrile $(35: 65),{ }^{17}$ so that their $t_{R}$ would be longer than that of picloram using the 20:80 $\left(\mathrm{v}: \mathrm{v}^{-1}\right)$ ACN:5.0 mmol L ${ }^{-1} \mathrm{H}_{3} \mathrm{PO}_{4}$ mobile phase. However, the presence of these triazines would require column cleaning to avoid crossover interference between analyses. Cleaning could be made by increasing either the elution time or the proportion of ACN in the mobile phase. The latter approach would require column reconditioning, which could be made by the stepwise elution approach. ${ }^{19}$ 
Table 1. Picloram recoveries obtained by the proposed SIC method and conventional HPLC-UV method with a packed particle $\mathrm{C}_{18}$ column for $0.50 \mathrm{mg} \mathrm{L}^{-1}$ picloram spiked waters collected at the Salto Grande (SG), Guarapiranga (G), Billings (B), Praia dos Namorados reservoirs and a Tap Water (TW) sample collected at the laboratory

\begin{tabular}{|c|c|c|c|c|c|}
\hline \multirow[t]{2}{*}{ Sample } & \multicolumn{2}{|c|}{ SIC } & \multicolumn{2}{|c|}{ HPLC } & \multirow[t]{2}{*}{ Relative Error $(\%)^{\mathrm{h}}$} \\
\hline & Conc. Found (mg L-1) & Recovery (\%) & Conc. Found (mg L-1) & Recovery (\%) & \\
\hline SG & $0.40 \pm 0.08^{\mathrm{a}}$ & 80 & $0.441 \pm 0.003^{\mathrm{a}}$ & 88.2 & -9.2 \\
\hline G & $0.51 \pm 0.02$ & 102 & $0.471 \pm 0.003$ & 94.2 & 8.3 \\
\hline B & $0.49 \pm 0.01$ & 98 & $0.47 \pm 0.01$ & 94 & 4.3 \\
\hline PN & $0.50 \pm 0.09$ & 100 & $0.51 \pm 0.02$ & 102 & -2.0 \\
\hline TW & $0.45 \pm 0.02$ & 90 & $0.43 \pm 0.01$ & 86 & 4.7 \\
\hline
\end{tabular}

a Standard deviation of 3 measurements; ${ }^{\text {b }}$ Relative error computed as $\left(\frac{S I C_{\text {conc. }}-H P L C_{\text {conc. }}}{H P L C_{\text {conc. }}}\right) \times 100$.

\section{Application to spiked waters}

Five river water samples free of detectable amounts of picloram were spiked with $0.50 \mathrm{mg} \mathrm{L}^{-1}$ of the herbicide, and let to stand for $24 \mathrm{~h}$ before analyses. Recoveries between 80 and $102 \%$ were found (Table 1). From the F test, no evidence of statistically significant differences was observed in the precision of the two methods at the $95 \%$ confidence level. Relative errors of -9.2 to $+8.3 \%$ were observed by comparing the results obtained by SIC with those ones obtained by HPLC. ${ }^{10}$ The $t$ test at $95 \%$ confidence level for comparison of mean results for each sample did not show evidences of statistically significant differences between the two methods.

The main drawback of the SIC system is the short life time of the guard columns (up to about 100-150 injections), which are often clogged, even filtering sample and mobile phases. The clogging increases the pressure needed for mobile phase pumping, leading to leakage through either the relief valve or through the rotary selection valve, altering the retention times of the analyte. Instrumental improvements are still needed for this relatively new and promising liquid chromatography technique to enhance its robustness. For instance, to overcome leakage problems, the change of the low pressure Cheminert ${ }^{\circledR}$ Valco10-port multi-position valve by another one capable to work at pressures up to $5000 \mathrm{psi}$ is recommended.

\section{Conclusion}

Sequential injection chromatography with UV detection was feasible to determine picloram concentrations in natural spiked waters at concentrations $>137 \mu \mathrm{g} \mathrm{L}^{-1}$ at a sampling frequency of about 60 analyses per hour. Consumption of $\mathrm{ACN}$ is $300 \mu \mathrm{L}$ per analysis, which is a significant advantage over conventional HPLC fitted to conventional $5 \mu \mathrm{m}$ packed particle column. This is an interesting feature, attending the demand for clean analytical methods that consume less reagents and solvents. ${ }^{22}$

\section{Acknowledgments}

The authors express their gratitude to Fundação de Amparo à Pesquisa do Estado de São Paulo (FAPESP) and Conselho Nacional de Desenvolvimento Científico e Tecnológico (CNPq) for the financial support and fellowships.

\section{References}

1. Cardoso, L. P.; Celis, R.; Cornejo, J.; Valim, J. B.; J. Agric. Food Chem. 2006, 54, 5968.

2. Groover, R.; Cessna, A. J.; Environmental Chemistry of Herbicides, Volume I, CRC Press: Boca Raton, Florida, USA, 1991.

3. Close, M. E.; Pang, L.; Watt, J. P. C.; Vincent, K. W.; Geoderma 1998, 84,45 .

4. Cerdeira, A. L.; dos Santos, N. A. G.; Pessoa, M. C. P. Y.; Gomes, M. A. F.; Lanchote, V. L.; J. Environ. Sci. Health, Part B 2005, 40, 159.

5. Palma, G.; Sanchez, A.; Olave, Y.; Encina, F.; Palma, R.; Barra, R.; Chemosphere 2004, 8, 763.

6. Pinho, A. P.; Matos, A. T.; Morris, L. A.; Costa, L. M.; Planta Daninha 2007, 25, 125.

7. Edgell, K. W.; Erb, E. J.; Wesselman, R. J.; Longbottom, J. E.; J. AOAC Int. 1993, 76, 1098.

8. Wells, M. J. M.; Michael, J. L.; Anal. Chem.1987, 59, 1739.

9. Wells, M. J. M.; Michael, J. L.; Neary, D. G.; Arch. Environ. Contamin. Toxicol. 1984, 13, 231.

10. Palma, G.; Sanchez, A.; Olave, Y.; Encina, F.; Palma, R.; Barra, R.; Chemosphere 2004, 57, 763.

11. Capiello, A.; Famiglini, G.; Berloni, A.; J. Chromatogr., A 1997, 768, 215.

12. Massaropi, M. R. C.; Machado, S. A. S.; Avaca, L. A.; J. Braz. Chem. Soc. 2003, 14, 113. 
13. dos Santos, L. B. O.; Masini, J. C.; Talanta 2007, 72, 1023.

14. Huclova, J.; Satinsky, D.; Karlicec, R.; Anal. Chim. Acta 2003, 494, 133.

15. Ruzicka, J.; Marshall, G. D.; Anal. Chim. Acta 1990, 237, 329.

16. Chocholous, P.; Solich, P.; Satinsky, D.; Anal. Chim. Acta 2007, 600, 129.

17. dos Santos, L. B. O.; Infante, C. M. C.; Masini, J. C.; J. Sep. Sci. 2009, 32, 494.

18. Chocholous, P.; Satinsky, D.; Sladkovsky, R.; Pospisilova, M.; Solich, P.; Talanta 2008, 77, 566.

19. Rigobello-Masini, M.; Penteado, J. C. P.; Liria, C. W.; Miranda, M. T. M.; Masini, J. C.; Anal. Chim. Acta 2008, 628, 123.
20. http://www.epa.gov/safewater/contaminants/basicinformation/ picloram.html\#five, accessed in December 2009.

21. Thompson, M.; Ellison, S. L. R.; Wood, R.; Pure Appl. Chem. 2002, 74, 835 .

22. Armenta, S.; Garrigues, S.; de la Guardia, M.; TrAC, Trends Anal. Chem. 2008, 27, 497.

Received: February 4, 2010

Web Release Date: April 27, 2010

FAPESP has sponsored the publication of this article. 